\title{
Adaptability of Folkways: Buddhist Thai vernacular houses of Songkhla Lake Basin
}

\author{
Supawadee Chuapram¹, Ornsiri Panin² \\ 1 Faculty of Architecture and Graduate school, Built Environment Program, Kasetsart University, \\ Bangkok; \\ School of Architecture and Design, Walailak University, 222 Thaiburi, Thasala District, \\ Nakhonsithammarat 80160, Thailand.
}

2 Faculty of Architecture, Kasetsart University, 50 Paholyothin Road, Jatujak, Bangkok 10900, Thailand.

csupawad@wu.ac.th

\begin{abstract}
This research has explored the relationships between community ecosystems and folkways in the context of modern development, especially how these relationships are manifested in the changing physical characteristics of their vernacular houses. Using qualitative methods and a holistic approach to study tradition and change, three Thai-Buddhist communities around Songkhla Lake Basin were selected for comparative study. Data were derived from documentary sources, direct and participant observation, in-depth interviews and architectural drawings. It was found that the traditional communities in different local micro-ecosystems were transformed to be a new characteristic of Southern Thai dwellings underlie the emergence of hybrid economic and society. However, kinship ties, their Buddhist beliefs and experience of adaptability reinforce the existent of local identities.

Keywords: Adaptability; Folkways; transformation; Community eco-system; Buddhist Thai, Vernacular house; Songkhla Lake Basin

eISSN 2514-751X C 2018. The Authors. Published for AMER ABRA cE-Bs by e-International Publishing House, Ltd., UK. This is an open-access article under the CC BY-NC-ND license (http://creativecommons.org/licenses/bync-nd/4.0/). Peer-review under responsibility of AMER (Association of Malaysian Environment-Behaviour Researchers), ABRA (Association of Behavioural Researchers on Asians) and cE-Bs (Centre for EnvironmentBehaviour Studies), Faculty of Architecture, Planning \& Surveying, Universiti Teknologi MARA, Malaysia.

DOI: https://doi.org/10.21834/aje-bs.v3i9.296
\end{abstract}




\subsection{Introduction}

Modern development has brought change, physical and cultural, to rural communities everywhere. There has long been a literature exploring the links between cultural practices, traditional lifestyles and local ecologies in the context of cultural modernization and economic development (reviewed, in Steward, 1979; Rapoport, 1969, 1994). More recently writers have specifically focused on the context of Thai traditional communities (Nartsupha \& Lertvicha, 1998; Ganjanapan, 2001; Pongpaiboon, 2001; Jarernsinolarn, 2002).

The objective of this research has been explored the relationships between community ecosystems and folkways of these communities in context of modern development especially how these relationships are manifested in the changing physical characteristics of vernacular houses. We specifically invoke the idea of community eco-system, by which we mean the rich and complex relationships between local community and its immediate local (micro-) eco-system - the ways in which the local community and its cultural practices are embedded and partly determine the transformations of the local eco-system.

The research has been seen the present change of the vernacular architecture in specific rural communities in the Songkhla Lake Basin area of southern Thailand.

\subsection{The Songkhla Lake Basin}

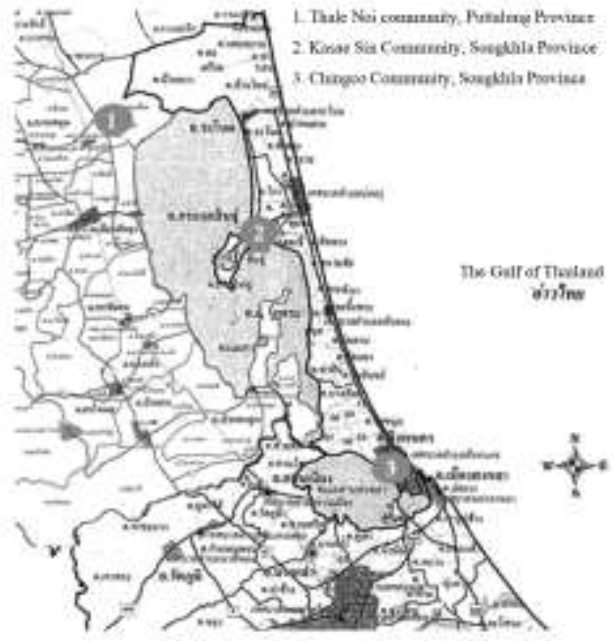

(a)

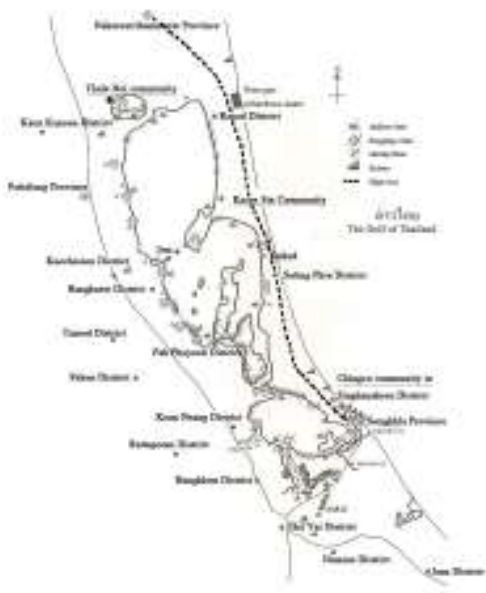

(b)

Fig. 1 (a): The location of three selected communities of Songkhla Lake Basin (b): Modern developments of Songkhla Lake Basin, Source: modified from Duangsuwan (2002) 

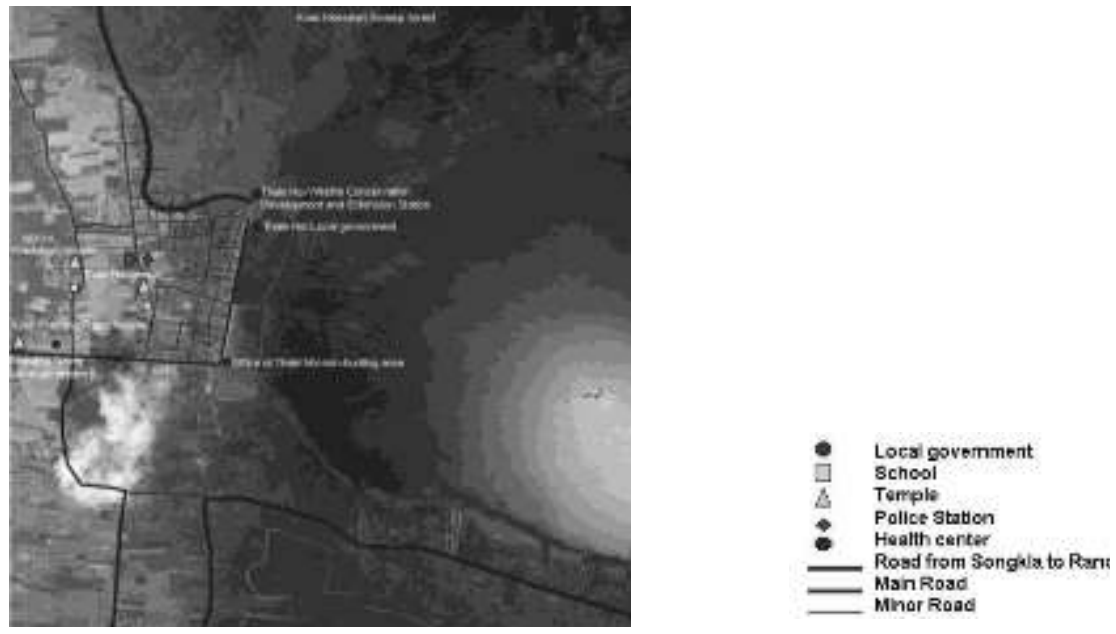

Fig 2: Thale Noi community, Source: modified from Royal Thai Survey Department (2002)
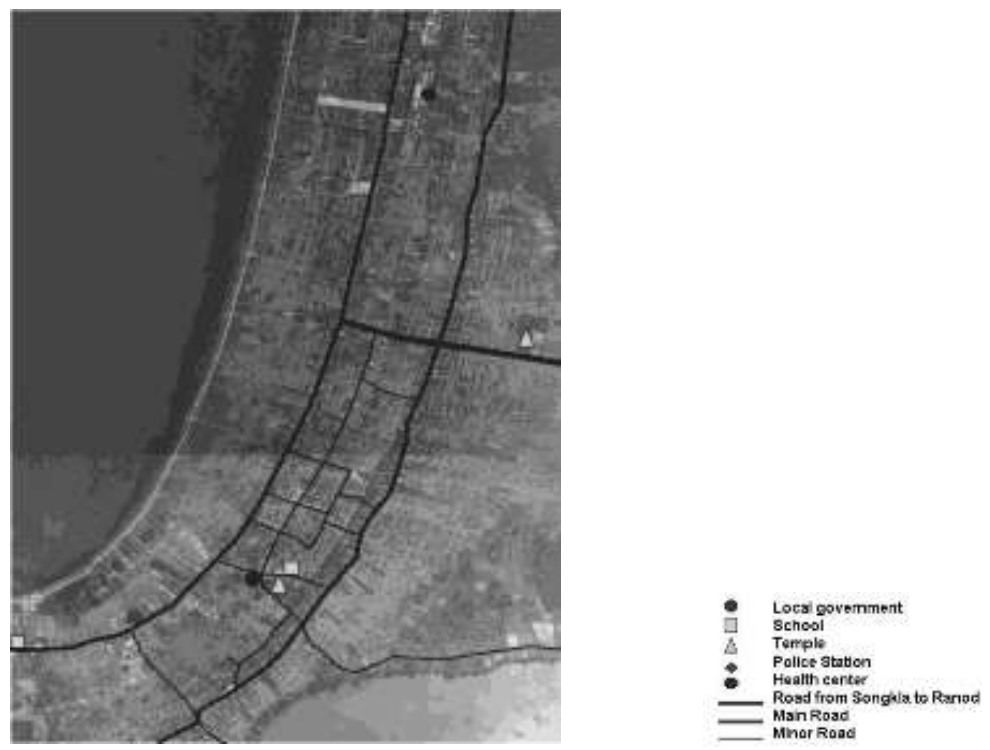

Fig 3: Krasae Sin community, Source: modified from Royal Thai Survey Department (2002) 

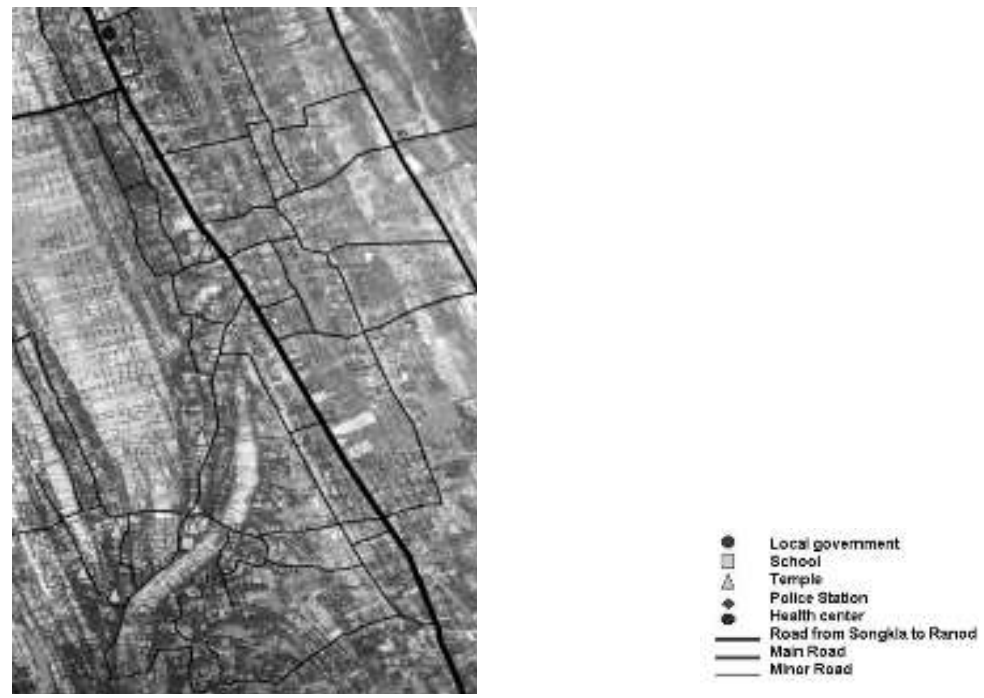

Fig 4: Chingco community, Source: modified from Royal Thai Survey Department (2002)

Songkhla Lake is the largest natural lake in the southern part of Thailand. Though classified a lake, it is geologically a lagoon complex divided into three distinct parts. The southern component opens to the Gulf of Thailand at the Songkhla city; its water is brackish, of about half the salinity of the Gulf. Further north, beyond a bottleneck is the Thale Luang. Finally, at the northern end, in the midst of a mangrove swamp, is Thale Noi, the one of the few surviving freshwater wetland ecosystems and has been protected as a Ramsar wetland since 1998. It displays lake, marsh, swamp forest. The central Thale Luang, by contrast, is an extensive freshwater lagoon while the southern stretch is characterised by its openness and links to the sea.

Three communities were selected for comparative study: Thale Noi community (in Phatthalung Province), Krasae Sin community and Chingco community (in Songkhla Province). In each community, 5 traditional houses were selected for study. Thai-Buddhist traditional communities established for a century or more, in decidedly different microecosystems and differently affected from modern development especially water management projects and transformations of waterways to terrestrial ways. Various and field research (participant observation, interviews). analytical approaches were adopted to study tradition and change, derived from documents and field rsearch (participant observation, interviews).

\subsection{Significant changes affecting local living}

Two sets of changes have affected the communities of Songkhla Lake Basin. The first relate 
to resource managements: a) A water gate was constructed in 1954 at Pakrawa canal in Ranod district to block sea water and thereby to enable 132 irrigation projects for rice plantation (Duangsuwan, 2002). This has directly affected the existing fishery regime and changed the peasant economy and lifestyle. b) Thale Noi (North Lake area) was announced to be a Ramsar site in 1998 (Office of Natural Resources and Environmental Policy and Planning, 1999). Local people became virtual outsiders to this process and an increasing specialization of functions affected the social space of the community. The lake has become shallower and aquatic ecosystems have changed, in turn differentially affecting livelihoods and local systems of production. The second set of changes relate to the transformation of waterways to terrestrial ways: the first highway from Songkhla city to Ranod district was constructed in 1973 (Pongpaiboon, 1993). The road as agent of modernization has changed community structure both physically and socially.

\subsection{Adaptability for survival: three case studies}

Thale Noi community's name refers to the name of the northern area of Songkhla Lake, where it is clustered; likewise Wat (Temple) Thale Noi also represents the relationship of the settlement with its natural environment. The ecosystem of swamp forest and wetland is the basis of local occupations that include fishery, paddy farming and handicrafts made from bulrush, and connects the community to other similar communities in a network of friendship called Kler khao Kler le (the friend from the mountain and the sea) with the waterway of the lake as the main route, reflecting the reality of an aquatic rural world. As the lake is common property of many communities, its use was historically managed via the circulating water that accompanied the change of seasons, until modern developments changed the mode of production from subsistence to mono-plantation, especially the paddy farming of Ranod district in the eastern part of the lake following 1954 construction of the water gate at Pakrawa canal to block sea water and enable irrigation (Duangsuwan, 2002). This action profoundly affected the shallow lake and thereby the fishermen of Thale Noi. With the declaration of Thale Noi as a Ramsar site in 1998, the conservation goal and linked tourism policy, pushed the villagers to the status of outsiders. Especially the road from Thale Noi to Ranod, though potentially an agent for prosperity, forced value changes on the villagers. New occupations, specifically service jobs, have led to new interactions with the environment. Yet, despite that, older collective occupations seem to be surviving.

Krasae Sin community's name means a city replete with water, again referring to the relationship with its environment. The term also refers to three districts and the harmony of communities in this place. Krasae $\mathrm{Sin}$ is a new district established in 1978 (Krasae Sin local administration, 2008). The centre is Tanod Duan village; likewise there is Wat Tanod Duan, where tanod refers to a sugar palm and hence the relation between the environment and local occupations, manufacturing from sugar palm. Their community ecosystem was traditionally one of alternating fresh and brackish water related to the seasonal circulation of water, until the modern developments of the water gate at Pakrawa canal and irrigation system since 1954 (Duangsuwan, 2002). The water is now mostly fresh and thus becomes 
the basis for new local occupations including paddy farming, manufacturing of sugar palm, fishery and raising cattle. This settlement is landward but near the lake in the south though far from the main access way. However, it is connected with other communities by both water and road. The first highway from Songkhla city to Ranod district, constructed in 1973 (Pongpaiboon, 1993), shifted activity from waterways to territorial ways, reinforced by the increasingly shallow lake. This affected folkways as the mode of production shifted to dependence on government and the market. There have been new occupations, labour in factories and construction sites, and a shift to collective occupation groups.

Chingco Community's name is ambiguous. Chingco means stealing cattle and might refer to some distinctive activity; however, it is also distorted from the word Chongkho (the name of a tree in the Thai language), possibly referring to the environment of this locality; it is also a distortion of the word Singora (the name of Singhanakhorn district) by which foreigners used to refer to this place. The community is in the south of Songkhla Lake. The community ecosystem is one of alternating brackish or sea water circulating seasonally, providing the bases to local occupations, include paddy farming, manufacturing of sugar palm, and raising cattle. There is the connecting Kler khao Kler le community network, with the waterway of the lake enabling exchange between communities, although the walkway has always been significant.

However, the modern development has taken its toll. The first highway from Songkhla city to Ranod district, constructed in 1973, divided the community in half; then Tinnasulanon Bridge, built in 1986, affected the community significantly. Chingco community was split into a tessaban (municipality) of Singhanakorn district, in consideration of its size, capacity and function rather than any sense of a co-existing community.

\subsection{Household transformations}

The data displayed above reveal processes of transformations in community economy and accordingly in households, consequent on aspects of a modern market economy inserting into a pre-modern, traditional, rural economy that could previously be seen as, in part, selfgenerating and self-renewing (Natsupha, 1997; Ganjanapan, 2001). Bloch (1932) coined the term 'nonsynchronism' to refer to the phenomenon of living in a range of different times at once and in the same place (Bloch, 1997). Nederveen Pieterse has likewise drawn attention to the way that globalisation produces a proliferation and hybridisation of modes of production and organisation. This principle of hybridisation is counterposed to the 'dual economy' split in traditional/modern sectors; instead we get an interpenetration of modes of production (Nederveen Pieterse, 1995: 50-51).

Fieldwork revealed households who could be seen as operating in two economies. While modern Thailand might be described in terms of dual economies in the sense argued by Boeke (1953), at the level of the household there seems to be more of a sense of interpenetration as suggested by Nederveen Pieterse - a sort of economic muddle. Older production practices persist; households in three communities are involved simultaneously in traditional production and informal exchange and in paid, formal sector employment - most 
notably government services but also factory and laboring employment.

The question is whether we are witnessing the 'clash of economies' (Boeke) or a hybridisation? The question is of some theoretical significance: the gist of Nederveen Pieterse's extended argument is that these situations of interpenetrating modes of production become sites of what Mann (1986) calls 'interstitial emergence' - of what are effectively new, emerging modes of production - and thereby important sources of social transformation or renewal.

The suggestion at this point in this place can detect fundamental economic and social transformation - the emergence of new ways of economic and social organisation. However, it is really only at the level of the household that this becomes visible.

\subsection{Dwelling transformations}

Southern Thai-Buddhist houses of Songkhla Lake Basin are similar in the painting of Wat (temple) Mudchimavad in Songkhla city as in other traditional depictions - timber houses built on stilts, with double roof and clay roof tiles.

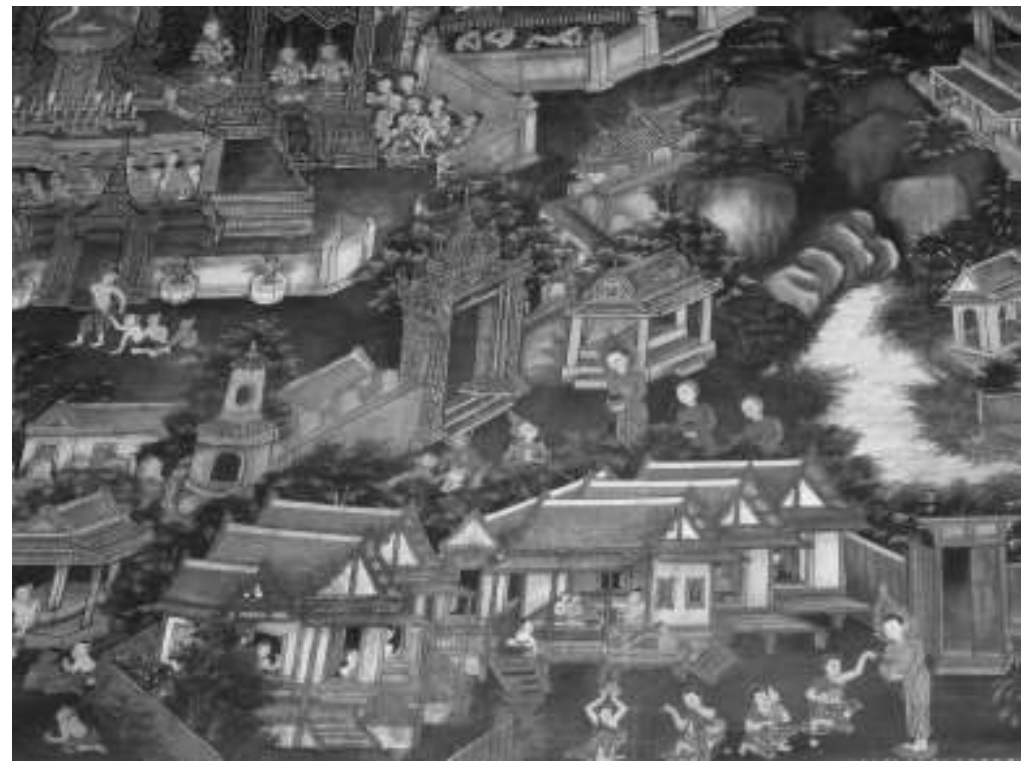

Fig 5: The painting of Wat (temple) Mudchimavad in Songkhla city

A number of authors, on the basis of survey, have written on the Thai vernacular house (Panin, 2008; Pisuttirattananon \& Maneechod, 1992; Pongpaiboon, 1999). The use of space is flexible in relation to the mode of subsistence and the physical environment; the main approach is typically from covered front-stairs to the semi-covered terrace, thence continuing 
to the main hall and bedroom. The kitchen was always separated in a pavilion adjoining the open terrace. The direction of the house was significant: the front of the house would face to the east although the kitchen building was separated to the back and located in what was really an adverse direction.

The relationships of kinship and of Buddhism always dominated the design and use of the house. The vertical dimension was associated with the deceased ancestors, the horizontal dimension with the family. The twin roof form in one sense represented this dichotomy. The direction of the sleeping household head was also significant: the most senior resident would sleep with head turned to the south; younger residents must not turn their feet in this direction when they sleep. The differentiated levels of the house's platforms and its steps also represent respect for seniority. The space under the house would not be used for habitation because of the respect to be accorded the household head as properly and respectfully elevated.

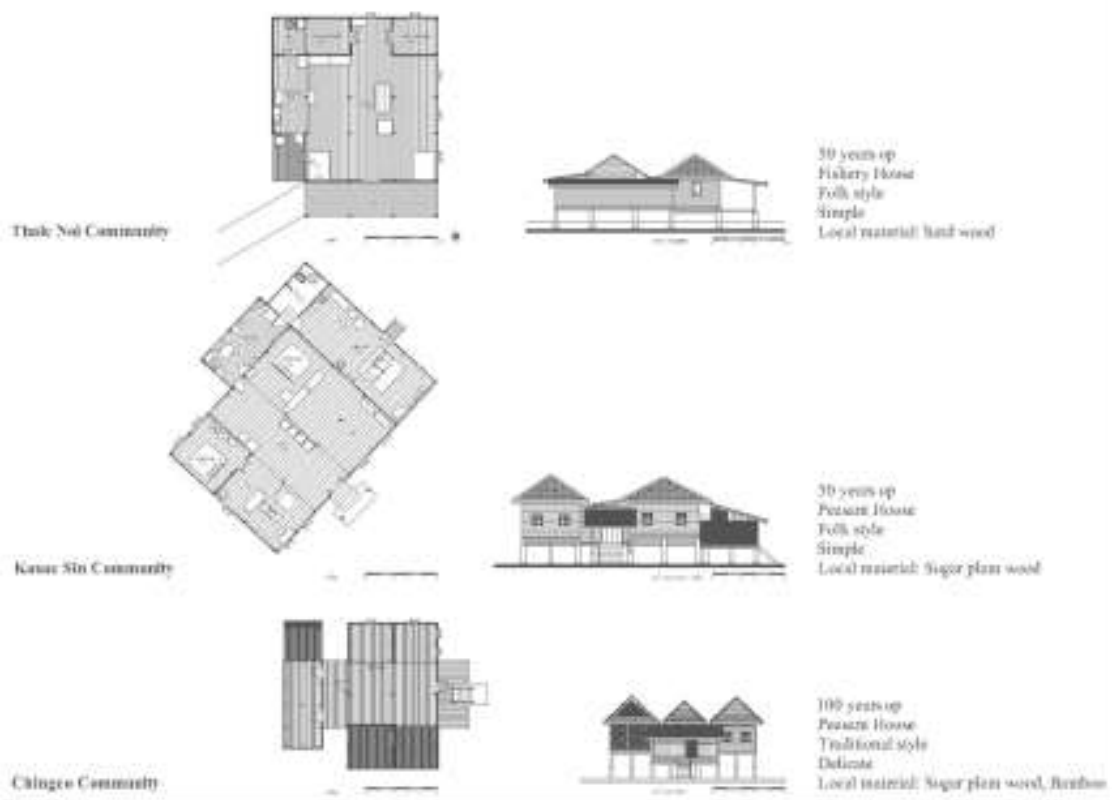

Fig 6: Physical characteristics of houses in three communities

The living space was to express their beliefs. However, despite these requirements of belief and respect, the living space was never static but would adapt in different ways to different conditions, as different contexts would transform the process of household living expressed in the vernacular house.

We have observed popular reactions of disappointment as visitors to indigenous Thai 
communities, consider the sorts of changes to houses summarized above - modern materials, low-pitched roofs replacing high-pitched, galvanized zinc plates rather than terra cotta or wood shingles, culturally-determined differences in floor levels abandoned, kitchens and toilets brought into the house. The 'passing of the real Thai house' is bemoaned. These reactions, however, miss the point: what is emerging is a new vernacular. They are an altogether new southern Thai.

These communities manifest the emergence of a new mode of economic and social organization, so they display a new architecture. Both are hybridized and 'muddled'. Simply, they might be the reality of an emerging Thailand.

Table 1: Vernacular houses and their characteristics in the three Songkhla Lake communities.

\begin{tabular}{|c|c|c|c|c|}
\hline & House & Thale Nol community & Krasae Sin community & Chingco community \\
\hline \multirow[t]{2}{*}{ 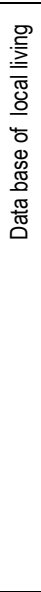 } & 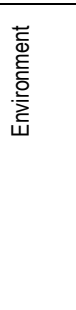 & $\begin{array}{l}\text {-Flat and swamp forest } \\
\text {-Biological diversity } \\
\text {-Building water gate and } \\
\text { irrigation } \\
\text {-Announced to be a Ramsar site } \\
\text {-Eco-tourism } \\
\text {-Department of Fisheries assume } \\
\text { authority in the zone } \\
\text {-Construction of a lake edge road }\end{array}$ & $\begin{array}{l}\text {-Flat and sand ridges } \\
\text {-Decreased biological diversity } \\
\text {-Government wants to change } \\
\text { structure of production and } \\
\text { villagers begin to comply. } \\
\text {-Kukud announced to be a } \\
\text { preservative area in } 1998 . \\
\text {-Change from waterway to } \\
\text { terrestrial way forces community } \\
\text { far from the other, older } \\
\text { community. }\end{array}$ & $\begin{array}{l}\text {-Flat and sand ridges } \\
\text {-Ancient trade junction: } \\
\text {-This place is near Songkhla city } \\
\text {-First road from Songkhla to } \\
\text { Ranod was built in } 1973 \text {. } \\
\text {-Tinnasulanon Bridge was built in } \\
1986 .\end{array}$ \\
\hline & $\frac{\stackrel{\infty}{\Phi}}{\bar{\Phi}}$ & $\begin{array}{l}\text {-Fishery, bulrush handicraft, } \\
\text { paddy farming, and fish farm. } \\
\text {-People built their houses as } \\
\text { present owners or are second } \\
\text { generation. } \\
\text {-An extended family living } \\
\text { together in the house or in } \\
\text { houses nearby. }\end{array}$ & $\begin{array}{l}\text {-Paddy farm, sugar palm } \\
\text { production, chicken farm, cattle } \\
\text { farming, fish farm and additional } \\
\text { service labour. } \\
\text {-People built their houses as } \\
\text { present owners or are second } \\
\text { generation. } \\
\text {-An extended family living } \\
\text { together in the house. }\end{array}$ & $\begin{array}{l}\text {-Paddy farm, sugar palm } \\
\text { production, cattle farm, and now, } \\
\text { additionally, service labour, } \\
\text { construction work and trade. } \\
\text {-The owners now are third } \\
\text { generation and not the people who } \\
\text { built the house. } \\
\text {-An extended family living in the } \\
\text { houses nearby but in the in same } \\
\text { area. }\end{array}$ \\
\hline \multirow[t]{2}{*}{ 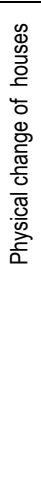 } & 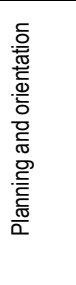 & $\begin{array}{l}\text {-Houses close together. If space } \\
\text { is available, they will dry bulrush. } \\
\text { Short-term crops. } \\
\text {-Most houses face east, thereby } \\
\text { facing the sea. } \\
\text {-Kitchen is adjacent to the house, } \\
\text { to the back or side. }\end{array}$ & $\begin{array}{l}\text {-Surrounded by a garden outside } \\
\text { and by a yard. Some have } \\
\text { paddy farm in front. A pond is } \\
\text { outside the house. } \\
\text {-Most houses face the east, but } \\
\text { some are now facing the road. } \\
\text {-Most houses have demolished } \\
\text { the kitchen and built it again } \\
\text { within the house. Most are facing } \\
\text { the new road. }\end{array}$ & $\begin{array}{l}\text {-Surrounded by a garden outside } \\
\text { and by a yard. A pond is outside } \\
\text { the house. } \\
\text {-Most of the houses face east, but } \\
\text { now some are facing the road. } \\
\text {-Most houses have demolished the } \\
\text { kitchen and built it again within the } \\
\text { house, mostly now facing the new } \\
\text { road. }\end{array}$ \\
\hline & 틍 & $\begin{array}{l}\text {-Most houses have twin hip } \\
\text { roofs. } \\
\text {-Fishery houses, Folk style }\end{array}$ & $\begin{array}{l}\text {-Most houses have twin hip roof, } \\
\text { although some have mixed hip } \\
\text { and gable roof forms. } \\
\text {-Peasant houses, Folk style } \\
\text {-Some minor adjustments to new } \\
\text { houses by changing the roof to } \\
\text { tile roofing with reduced slope. }\end{array}$ & $\begin{array}{l}\text {-Most houses have twin gable roof } \\
\text { in Thai-style, although some } \\
\text { houses are in triple form. } \\
\text {-Peasant house, Traditional style }\end{array}$ \\
\hline
\end{tabular}




\begin{tabular}{|c|c|c|c|c|}
\hline & 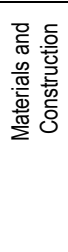 & $\begin{array}{l}\text {-Hardwood used from the forest } \\
\text { near the community. The clay } \\
\text { roof tiles were from Ko Yo, } \\
\text { Songkhla, but are no longer in } \\
\text { production. } \\
\text {-Use of new materials to repair } \\
\text { such as galvanized zinc plates } \\
\text { and precast concrete slabs. }\end{array}$ & $\begin{array}{l}\text {-Use of hardwood from Puttalung } \\
\text { and of sugar palm wood for } \\
\text { joists. Tiles were produced in the } \\
\text { communities themselves but now } \\
\text { stopped. } \\
\text {-Use of new materials to repair } \\
\text { such as galvanized zinc plates, } \\
\text { bricks. }\end{array}$ & $\begin{array}{l}\text {-Use of hardwood from Puttalung } \\
\text { and use of bamboo for walls. } \\
\text {-Clay tiles were from Ko Yo which } \\
\text { is close by, but now stopped. } \\
\text {-Use of new materials to repair } \\
\text { such as galvanized zinc plates, } \\
\text { bricks. } \\
\text {-Some have double beams for } \\
\text { structural strength. }\end{array}$ \\
\hline \multirow[t]{2}{*}{ 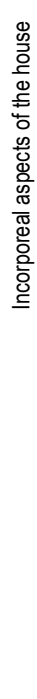 } & 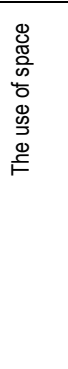 & $\begin{array}{l}\text {-The differences in levels in the } \\
\text { house have been reduced, in } \\
\text { part to prevent flooding. } \\
\text {-Space in the house's terrace } \\
\text { and pathway in the front is now } \\
\text { used for productive activity: } \\
\text { specifically, bulrush handicraft. } \\
\text {-The front of the bedroom has a } \\
\text { shelf for the shrine to ancestors. } \\
\text {-The addition of toilets within the } \\
\text { back or to the side. } \\
\text {-Use the space under the house } \\
\text { for storage and drying bulrush. }\end{array}$ & $\begin{array}{l}\text {-Some houses use the space } \\
\text { under the house for parent's } \\
\text { bedroom for reasons of } \\
\text { convenience. } \\
\text {-The level of the pavilion is } \\
\text { reduced down to the ground. } \\
\text {-The front of the bedroom has a } \\
\text { shelf for the shrine to ancestors. } \\
\text {-Toilets are added in the back of } \\
\text { the houses. }\end{array}$ & $\begin{array}{l}\text {-Some houses use the space } \\
\text { under the house for parent's } \\
\text { bedroom for reasons of } \\
\text { convenience. } \\
\text {-The level of the pavilion is } \\
\text { reduced down to the ground. } \\
\text {-The front of the bedroom has a } \\
\text { shelf for the ancestor's shrine. } \\
\text { Some houses have Chinese } \\
\text { guardian spirit and ceiling } \\
\text { honouring the grandparents. } \\
\text {-Toilets are added within the back } \\
\text { or side of the houses. }\end{array}$ \\
\hline & 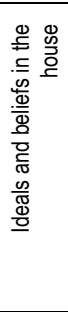 & $\begin{array}{l}\text {-The householder's head is } \\
\text { turned to the south when they } \\
\text { sleep and the feet of others may } \\
\text { not be similarly turned. } \\
\text {-Respect for the head in not } \\
\text { using the basement area. } \\
\text {-The owner's position will be } \\
\text { pointed towards the spirit } \\
\text { column; there will be appropriate } \\
\text { respect and ceremony. } \\
\text {-A shrine in front of the house. }\end{array}$ & $\begin{array}{l}\text {-The head is turned to the south } \\
\text { when the owner sleeps; feet of } \\
\text { others may not be turned } \\
\text { towards the major pavilion. } \\
\text {-There is a spirit column } \\
\text { ceremony and respect is to be } \\
\text { observed. Owner of the house } \\
\text { cannot be pointed at. }\end{array}$ & $\begin{array}{l}\text {-The head is turned to the south } \\
\text { when the owner sleeps; others' } \\
\text { feet may not be turned towards the } \\
\text { major pavilion. } \\
\text {-There is a spirit column ceremony } \\
\text { and respect is to be observed. } \\
\text { Owner of the house can not be } \\
\text { pointed at. } \\
\text {-A shrine in front of the house. } \\
\text { Some have a pavilion and a pond } \\
\text { to accommodate the public. }\end{array}$ \\
\hline
\end{tabular}

\subsection{Conclusion}

The stories of these villages over 50 years and observations of their present states reveal a great array of transforming changes. The transformations are different in each of the three villages observed here, in part due to their different community micro-ecologies and different histories and cultural practices. While the people's Buddhist religion and cultural practices remain strong, a stabilizing force in a time of otherwise great change.

There is a temptation to look at the consequence of these transformations through a lens of nostalgia, mourning the passing of old economies and lifestyles, of what were regarded as indigenous vernacular houses. However, what we are really seeing are manifestation of what might well be the emergence of a new form of Thai society. First, we observe an ongoing process of economic hybridity as old and new forms of production, exchange and consumption seem to fuse into something quite original. Second, old houses transform (lowpitched roofs, simplified floor levels, new materials, new spatial arrangements), new houses are built with scant acknowledgement of older traditions, yet what is emerging can also be seen as a new vernacular. It might be strongly at variance with houses of the past but it is also distinctive and an expression of the emerging, hybrid economy and society. 
The study highlights the adaptability of Southern Thai people changes their vernacular dwellings in micro-ecosystem and modern developments for survival. The recommendation for further study, the holistic approach is important in vernacular architecture study to understand truly diversity and change of folkways, as living culture.

\section{Acknowledgement}

This paper is based on Supawadee Chuapram's Ph.D. dissertation which was financially supported from the Thailand Research Fund through the Royal Golden Jubilee Ph.D. Program. Special thank for Prof. Ross King, the co-advisor. We would like to thank the residents and all instructors of Built Environment Program, Faculty of Architecture and Graduate school, Kasetsart University.

\section{References}

Bloch, E. (1997)."Nonsynchronism and the obligation to its dialectics", New German Critique, 11, 22-38.

Boeke, J.H. (1953). Economics and Economic Policy of Dual Societies as Exemplified by Indonesia. New York: Institute of Pacific Relations.

Ganjanapan, A. (2001). Complex methods of communities' research: Dynamics and potential of communities in the development. Bangkok: The Thailand Research Fund. [Thai book]

Jarernsinolarn, C. (2002). Development discourse: power, knowledge, truth, identity, and otherness. Bangkok: Vipasa Press. [Thai book]

Mann, M. (1986). The sources of social power. Cambridge: Cambridge University Press.

Nartsupha, C. \& Lertvicha, P. (1998). Thai cultural villages. Bangkok: Srang-San Press. [Thai book]

Nederveen Pieterse, J.P. (1995). "Globalization as hybridisation", in Global Modernities, Eds M. Featherstone, S. Lash, R. Robertson. London: Sage, 45-68.

Noparatnaraporn, C. (2004). "Transforming 'unbounded' nature: the evolution of a Thai cultural landscape". Ranaeang, 4, 204-215.

Noparatnaraporn, C. \& King, R. (2007). "Memory or Nostalgia: The Imagining of Everyday Bangkok". SOJOURN, 22(1), 57-82.

Panin, O. (2008). Thai-Tai vernacular house. Bangkok: The Thailand Research Fund. [Thai book]

Pisuttirattananon, M. \& Maneechod, C. (1992). Southern Thai vernacular houses. Songkhla: The Institute for Southern Thai Studies, Thaksin University. [Thai book]

Pongpaiboon, S. (1993). "Constraints and cultural factors with the development of communities around Songkhla Lake". Thaksinkadee Journal, 3(1), October-March, 55-66. [Thai paper]

Pongpaiboon, S. (1999). "Southern Thai vernacular house". Southern Thai Cultural Encyclopaedia, 16: 7704- 
Chuapram, S., \& Ornsiri Panin, O. / Asian Journal of Environment-Behaviour Studies (ajE-Bs), 3(9) Jul / Aug 2018 (p.15-26)

7721. [Thai book]

Rapoport, A. (1969). House form and culture. Englewood Cliffs, N.J.: Prentice-Hall.

Rapoport, A. (1994). "Spatial organization and the built environment". Companion encyclopaedia of anthropology. London and New York: Routledge, 460-502. 